Research Article

Open Access

\title{
Comparation and Estimation of Secreted Frizzled-Related Protein 4 in Diabetic Patients
}

Vasukidevi Ramachandran ${ }^{\star}$

Associate Professor, Department of Biomedical Engineering, Bharath University Chennai-600073, 173, Agaram Road, Selaiyur, Tamil Nadu, India

\section{Article Info}

\section{*Corresponding author:} Vasukidevi Ramachandran

Associate Professor

Department of Biomedical Engineering Bharath University, Chennai-600073, 173 Agaram Road, Selaiyur

Tamil Nadu, India

E-mail: vasukideviram@gmail.com

Received: May 18, 2017

Accepted: June 9, 2017

Published: June 16, 2017

Citation: Ramachandran V. Comparation and Estimation of Secreted Frizzled-Related Protein 4 in Diabetic Patients. Madridge J Immunol. 2017; 1(1): 10-12. doi: $10.18689 / \mathrm{mjim}-1000103$

Copyright: (c) 2017 The Author(s). This work is licensed under a Creative Commons Attribution 4.0 International License, which permits unrestricted use, distribution, and reproduction in any medium, provided the original work is properly cited.

Published by Madridge Publishers

\begin{abstract}
Recent evidence suggests that serum secreted frizzled-related protein 4 (SFRP4) may affect $\beta$-cell function in diabetic patients. SFRP4 is highly expressed in the pancreatic islets, and its levelincreases several years before diabetes diagnosis. 503 patients with impaired glucose tolerance (IGT) and normal glucose tolerance (NGT) were investigated to study the relationship between SFRP4 levels and the first-phase of glucose-stimulated insulin secretion, glucose metabolism and inflammation along with chronic ailments like hypertension, renal disease and cardio vascular problems. Majority of the patients belong to the low socio-economic groups of age groups 30-60 years. Among the 503 participants, 407 were males and 96 were females. The following parameters: Waist Hip Ratio, Blood Pressure, FBS (Fasting Blood Sugar), PPBS (Post Prandial Blood Sugar) ECG (Electrocardiogram) were also measured in the study. With reference to prior literature of data concerned with diabetes and normal people. SFRP4 levels were measured by ELISA. SFRP4 levels were associated with a higher risk of developing type 2 diabetes (T2DM). Further research is warranted to assess whether SFRP4 estimation will be a useful tool to detect the diabetes in the early stage in general population.
\end{abstract}

\section{Keywords \& Abbreviations}

Diabetes, IGT: impaired glucose tolerance, NGT: normal glucose tolerance, SFRP4: secreted frizzled-related protein,T2DM: type 2 diabetes, ELISA.

\section{Introduction}

Comparison and estimation of SFRP4 biomarker to identify the high-risk individuals are to be targeted for the prevention of type 2 diabetes (T2DM) is in the early stages of research. The secreted frizzled-related protein 4 (SFRP4) is highly expressed in the pancreatic islets, and its levels increases several years before diabetes diagnosis. The main feature and importance of this SFRP4 is more on T2DM patients suggesting that SFRP4 may have a role in glucose metabolism. The receptors for SFRP4 have been found in many organs of our body including pancreatic $\beta$ cell and its effects on metabolism and regulating the body weight. With reference to previous researches concerning with diabetes and normal diabetes patients, we need to step further to next generations [1-2]. 


\section{Materials and Methods}

A total of 503 patientswere included in the study, of which 407 were males and 96 were females. The study included studying the following parameters: Blood pressure, FBS (Fasting blood sugar), PPBS (Post prandial blood sugar) ECG (Electrocardiogram). In the ASSAY TECHNIQUE, BGMLT ELISA KIT was used for quantitative determination of SFRP4. By using quantitative sandwich enzyme immune assay technique the SFRP4 level was estimated.

\section{Results}

The diabetes and normal patients information were collected from 503 participant sand were analyzed using statistical program SPSS 15.0 and the descriptive statistics for the qualitative and quantitative parameters. The details are presented in Table 1 and Table 2. Chi-square test was used to find the association between morbidity and SFRP4 abnormality with $5 \%$ level of significance. The values presented, are within parentheses represents the percentages. In the present study, the majority 407 (80.9\% of them were males compared to $96(19.1 \%)$ females ranging between the age group of 30 to 60 years with a proportion of 344 (68.4\%) abnormal waist hip ratio. Mean \pm SE (Mean) of SBP/DBP were observed to be $125.3 \pm 0.6 / 80.3 \pm 0.4$ and the fasting glucose as $93.8 \pm 0.6$ with a post pron dial $139.7 \pm 0.9$.

A high level of SFRP4 level was observed among them was $38.5 \pm 0.6$. The Prevalence of diabetes and normal diabetes subjects were 18 (3.6\%), hypertension 29(5.8\%) and a negligible case of $1(0.2 \%)$ with both conditions by attaining our first objective.

Table 1: Descriptive statistics for qualitative information

\begin{tabular}{|c|c|c|}
\hline 1 & Age (years) & \\
\hline & $\begin{array}{l}31-40 \\
41-50 \\
51-60 \\
\end{array}$ & $\begin{array}{l}118(23.5) \\
230(45.7) \\
155(30.8)\end{array}$ \\
\hline \multirow[t]{2}{*}{2} & Sex & \\
\hline & $\begin{array}{l}\text { Male } \\
\text { Female }\end{array}$ & $\begin{array}{c}407(80.9) \\
19.1) \\
\end{array}$ \\
\hline \multirow[t]{2}{*}{3} & Systolic BP (mmHg) & \\
\hline & $\begin{array}{l}<140 \\
\geq 140\end{array}$ & $\begin{array}{r}411(81.7) \\
92(18.3) \\
\end{array}$ \\
\hline \multirow[t]{2}{*}{4} & Diastolic BP (mmHg) & \\
\hline & $\begin{array}{l}<90 \\
\geq 90 \\
\end{array}$ & $\begin{array}{c}371(73.8) \\
6.2)\end{array}$ \\
\hline \multirow[t]{2}{*}{5} & Fasting BS (mg\%) & \\
\hline & $\begin{array}{c}<110 \\
110-120\end{array}$ & $\begin{array}{c}479(95.2) \\
24(4.8)\end{array}$ \\
\hline \multirow[t]{2}{*}{6} & Post Prondia IBS (mg\%) & \\
\hline & $\begin{array}{c}<140 \\
140-160 \\
\end{array}$ & $\begin{array}{c}460(91.5) \\
43(8.5) \\
\end{array}$ \\
\hline \multirow[t]{2}{*}{7} & SFRP4 Level & \\
\hline & $\begin{array}{l}<15 \mathrm{pg} \\
\geq 15 \mathrm{pg}\end{array}$ & $\begin{array}{c}18(3.6) \\
6.4)\end{array}$ \\
\hline \multirow[t]{2}{*}{8} & Nil & \\
\hline & $\begin{array}{c}\text { Prediabetes } \\
\text { Diabetes\&Hypertension } \\
\text { Hypertension }\end{array}$ & $\begin{array}{l}18(3.6) \\
1(0.2) \\
29(5.8)\end{array}$ \\
\hline
\end{tabular}

Table 2: Descriptive statistics for quantitative information

\begin{tabular}{|c|c|c|c|c|}
\hline S.No & VARIABLES & RANGE & MEAN & SE (MEAN) \\
\hline 1 & Age (years) & $30-60$ & 46.3 & 0.31 \\
\hline 2 & SBP $(\mathrm{mmHg})$ & $90-180$ & 125.3 & 0.61 \\
\hline 3 & DBP $(\mathrm{mmHg})$ & $60-110$ & 80.3 & 0.40 \\
\hline 4 & FBS $(\mathrm{g} \%)$ & $62-172$ & 93.8 & 0.65 \\
\hline 5 & PPBS $(\mathrm{g} \%)$ & $91-320$ & 139.7 & 0.93 \\
\hline 6 & SFRP4 Level & $5-85$ & 38.5 & 0.63 \\
\hline
\end{tabular}

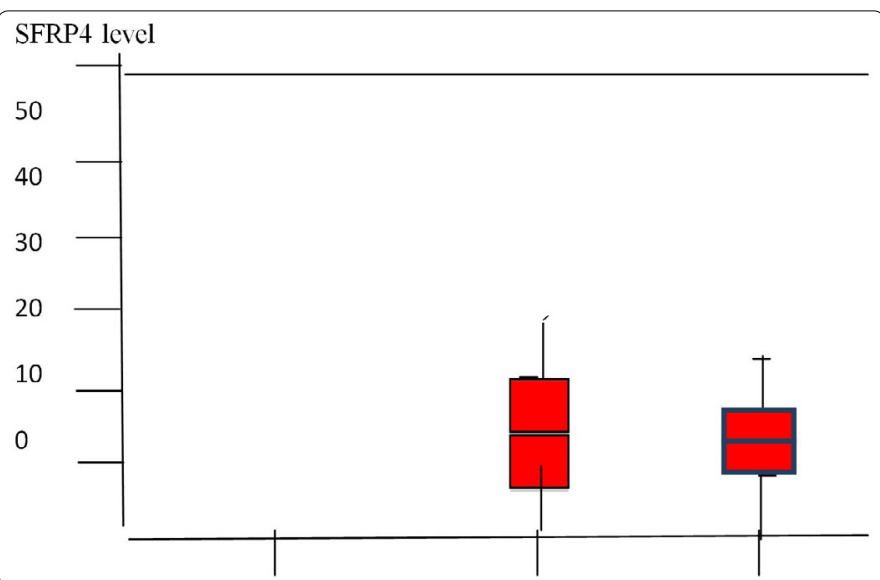

Figure. 1 Box-plot for 48 morbid cases with SFRP4Level highlights the Jenkins Box-Plot of SFRP4level for 48 morbid cases. Pearson Chi-Square of $17.37(P=0.000)$ implies a statistically significant association, BP of $143.2 \pm 2.7 / 87.1 \pm 1.7$

\section{Discussion and Conclusion}

In all diabetes and normal population study, especially in Kanchipuram District of Tamil Nadu, India the females outnumbered male in getting T2DM whereas in this study, the male outnumbered females around $80.9 \%$. In the case of SFRP4 male patients outnumbered the females patients. Similarly 503 patients were recruited as they were known to be prone for diabetic and metabolic syndrome which were always high. In this study, $76 \%$ of the patients were in the age group of 41-60 years.

In this location of study majority of the patients were of short stature. The diabetes patients in our this study had a waist hip ratio $>1$ i.e $68.4 \%$ (344) With reference to hypertension, this study revealed systolic hypertension around $18.3 \%$ and diastolic hypertension around $26.2 \%$

In this study, among the diabetes and normal patients, with same age group in this district around 70\% had T2DM where as in this study, none of them showed any frank diabetes and just around $2 \%$ were showing pre-diabetic level symptoms. In strict sense no one has Diabetes. After considering all the parameters especially none of were diabetic. Further study on the estimation of SFRP4, revealed around $96.4 \%$ people showing higher level of SFRP4 (more than $15 \mathrm{pg}$ ). Only 3.6\% levels were low (less than $5 \mathrm{pg}$ ). These results correlate with the pre-diabetic patients. Previous studies revealed that in diabetes patients with normal patients had low SFRP4 level. In the present study, SFRP4 levels were high compared to the previous studies. In conclusion, SFRP4 plays a vital role in preventing the diabetes, probably by means of insulin secretion and 
sensitization, through SFRP4. SFRP4 secretions were associated with a higher risk of developing T2DM. Further research is warranted to assess whether SFRP4 estimation will be a useful tool to detect the early diabetes of next generation in general population [3-8].

\section{References}

1. Hoffmann, Michael M, Hoffmann author, Christian Werner, Michael Böhm, Ulrich Laufs and Karl Winkler, et al. Association of secreted frizzled-related protein 4 (SFRP4) with type 2 diabetes in patients with stable coronary artery disease. Cardiovascular Diabetology. 2014; 13: 155. doi: 10.1186/s12933-014-0155-2

2. Buchanan TA, Xiang AH, Peters RK, et al. Preservation of pancreatic $\beta$-cell function and prevention of type 2 diabetes by pharmacological treatment of insulin resistance in high-risk hispanic women. Diabetes. 2002; 51: 2796-2803. doi: 10.1007/s11892-013-0363-2

3. Dennis $S$, Aikawa M, Szeto WD, Amore PA, Papkoff J. A secreted frizzled related protein, FrzA, selectively associates with Wnt-1 protein and regulates wnt-1 signaling. J Cell Sci. 1999; 112: 3815- 3820.
4. Mahdi $T$, Hänzelmann $S$, Salehi $A$, et al. Secreted frizzled-related protein 4 reduces insulin secretion and is overexpressed in type 2 diabetes. Cell Metab. 2012; 16: 625-633. doi:10.1016/j.cmet.2012.10.009

5. Mohan V, Amutha A, Ranjani $\mathrm{H}$, et al. Associations of $\beta$-cell function and insulin resistance with youth-onset type 2 diabetes and prediabetes among Asian Indians. Diabetes Technol Ther.2013; 15: 315322. doi: 10.1089/dia.2012.0259

6. Relationship between serum secreted frizzled-related protein 4 levels and the first-phase of glucose-stimulated insulin secretion in individuals with different glucose tolerance Article in Endocrine Journal. 2015; 62: 8. doi: 10.1507/endocrj.EJ15-0212

7. K Bergmann, et al. Secreted Frizzled-Related Protein 4 (SFRP4) and Fractalkine (CX3CL1) Potential New Biomarkers for $\beta$-Cell Dysfunction and Diabetes. Clin Bio chem. 2014; 47 (7-8): 529-532. doi: 10.1016/j. clinbiochem.2014.03.007

8. Wilson C. Diabetes: SFRP4-a biomarker for islet dysfunction?. Nature Reviews Endocrinology. 2013; 9: 65. doi: 10.1038/nrendo.2012.232 